Journal of EST, Volume 1, Nomor 1 Juni 2015 hal 12- 26

ISSN: 2460-1497

\title{
MODEL PEMBELAJARAN BERBASIS MASALAH SETTING KOOPERATIF UNTUK MENINGKATKAN DAYA MATEMATIS DAN KETERAMPILAN SOSIAL
}

\author{
Japar \\ Ahli Pendidikan Matematika \\ Balai Diklat Keagamaan Semarang, Indonesia \\ Japar_sidik1@yahoo.co.id
}

\begin{abstract}
The research aimed at discovering the description of mathematics learning in MTs and obtaining PBMSK (Problem-based learning of Cooperative Setting) model which was valid, practical, and effective to improve mathematical power and social skills of class VIII students at MTs. Negeri (Public MTs) Model Makassar. The study was a research and development which referred to Plomp's (1997) model development. The data analysis was conducted quantitatively to answer whether the model developed had already met valid, practical and effective criteria. The products of the study consisted of: model book, teacher's book, student's book, lesson plan, student's worksheet, and learning result test with the validity level extremely valid which had met valid criteria. The implementation of model was implemented entirely and had met practicality criteria. The effectiveness of model consisted of: learning completeness excellent, learning management excellent. Student's responses on PBMSK model: (1) must of the student expressed delight and, interested, and (2) Must of the student's said that student worksheet and text book easy to read, interesting, simple language, and the students' activities were fairly high and still at the ideal time interval tolerance which had been determined. The results indicated that it had met effective criteria. Therefore, the objective to obtain qualified PBMSK model which fulfilled valid, practical, and effective criteria had been achieved.
\end{abstract}

Keywords: Model development, PBMSK model, valid, practical, and effective

\begin{abstract}
ABSTRAK
Penelitian ini bertujuan untuk memperoleh gambaran pembelajaran matematika di MTs dan memperoleh model PBMSK yang valid, praktis, dan efektif untuk meningkatkan daya matematis dan keterampilan sosial siswa kelas VIII MTs. N Model Makassar. Penelitian ini termasuk jenis penelitian dan pengembangan (Research and Development atau $R \& D$ ) yang mengacuh pada pengembangan model yang dikemukakan oleh Plomp (1997). Teknik analisis data dilakukan secara kuantitatip untuk menjawab apakah model yang dikembangkan sudah memenuhi kriteria valid, praktis, dan efekti?. Produk yang dikembangkan terdiri atas: buku model, buku guru, buku siswa, RPP, LKS, dan THB dengan tingkat kevalidan yang sangat valid. Keterlaksanaan model adalah terlaksana seluruhnya. telah memenuhi kriteria kepraktisan. Keefektifan model terdiri atas: ketuntasan belajar sangat baik, pengelolaan pembelajaran sangat baik. Respons siswa terhadap penerapan model PBMSK, yaitu: (1) Hampir semua siswa menyatakan senang, (2) sangat berminat, dan (3) LKS dan buku siswa dinyatakan sangat mudah dibaca, sangat menarik, dan bahasanya sangat mudah dipahami, dan aktivitas siswa cukup tinggi dan masih berada pada interval toleransi waktu ideal yang ditetapkan,hal ini menunjukkan telah memenuhi kriteria keefektifan telah terpenuhi. Dengan demikian, tujuan memperoleh model PBMSK yang berkualitas yang memenuhi kriteria valid, praktis, dan efektif telah tercapai.
\end{abstract}

Kata Kunci: Pengembangan model, Model PBMSK, valid, praktis, dan efektif

\section{PENDAHULUAN}

Menurut Permendiknas No. 22 Tahun 2006, pembelajaran matematika sebaiknya menekankan pada pemahaman konsep matematika, bernalar (reasoning), memecahkan masalah (problem solving), komunikasi (communication), ataupun pada pemahaman (understanding). Dengan strategi 
pembelajaran seperti ini, kadar keaktifan siswa menjadi lebih tinggi.

Strategi pembelajaran matematika sebaiknya didesain agar pembelajaran berubah dari paradigma belajar yang berpusat pada guru, pada pembelajaran yang berpusat pada siswa (student centered approach). Menurut Monaghan (2011; 428), I found that using communities of practice as a learning strategy was an effective way to help students develop their skills to be self-directed collaborative learners, artinya dengan melibat siswa belajar secara berkelompok merupakan cara yang efektif untuk mengembangkan keterampilan berpikir.

Berdasarkan penelitian sebelumnya yang dilaksanakan pada tanggal 16 Januari 2013 di MTs. Negeri Model Makassar, menunjukkan bahwa prestasi belajar siswa MTs.N Model Makassar untuk mata pelajaran matematika khususnya daya matematis masih rendah, yaitu: (1) pemahaman konsep 41,73: (2) penalaran matematis 40,79; (3) pemecahan masalah 17,31; (4) koneksi matematis 26,35; dan (5) komunikasi matematis 40,32. Sedangkan, gambaran keterampilan sosial sebagai berikut: (1) empati yang terdiri atas: memadai 30,0\%; cukup memadai $45,5 \%$; kurang memadai $12,0 \%$; dan tidak memadai $5,5 \%$; (2) kerjasama yang terdiri atas: memadai $23,0 \%$; cukup memadai $37,0 \%$; kurang memadai $25,0 \%$; dan tidak memadai $15,0 \%$; (3) toleransi yang terdiri atas: memadai $28,5 \%$; cukup memadai $35,5 \%$; kurang memadai $21,0 \%$; dan tidak memadai $17,0 \%$; (4) solidaritas yang terdiri atas: memadai 40,0\%; cukup memadai $35,0 \%$; kurang memadai $11,5 \%$; dan tidak memadai $13,5 \%$ (5) demokratis yang terdiri atas: memadai $29,0 \%$; cukup memadai $34,0 \%$; kurang memadai $18,0 \%$; tidak memadai $19,0 \%$ (6) komunikasi yang terdiri atas: memadai $28,0 \%$; cukup memadai $45,0 \%$; kurang memadai $16,0 \%$; dan tidak memadai $11,0 \%$

Menurut Suwarsono (dalam Suradi, 2005: 9) kesulitan siswa dalam mempelajari matematika tidak terlepas dari strategi pengajaran yang selama ini digunakan di sekolah-sekolah Indonesia, yaitu strategi pengajaran klasikal dengan metode ceramah sebagai metode utama. Sedangkan menurut Slavin (2005) bahwa teknik- teknik pembelajaran kooperatif lebih unggul dalam meningkatkan hasil belajar dibandingkan dengan pengalaman-pengalaman belajar individual atau kompetitif. Selanjutnya menurut hasil penelitian Hsiung, C.-M. (2011: 119) bahwa,"Since the time on task was carefully monitored, the higher academic performance of the students in the cooperative learning condition suggests that cooperative learning is more effective than individualistic learning".

Hasil penelitian tersebut menunjukkan bahwa pembelajaran kooperatif lebih efektif daripada pembelajaran individual dalam meningkatkan prestasi akademik siswa apabila diawasi dengan sebaik-baiknya. Sedangkan menurut Tan (Rusman, 2011: 245) problem based learning (PBL) atau pembelajaran berbasis masalah (PBM) merupakan inovasi dalam pembelajaran karena kemampuan berpikir siswa betul-betul dioptimalisasikan melalui proses kerja kelompok atau tim yang sistematis, sehingga siswa dapat memberdayakan, mengasah, menguji, dan mengembangkan kemampuan berpikirnya secara berkesinambungan. Siswa memilih masalah yang menarik untuk dipecahkan, sehingga mereka termotivasi berperan aktif dalam belajar.

Berdasarkan permasalahan di atas, penulis termotivasi untuk melakukan penelitian dan pengembangan model pembelajaran berbasis masalah setting kooperatif (PBMSK). Dengan pertimbangan pengetahuan penulis dan berdasarkan kajian beberapa hasil penelitian, belum ada yang melakukan penelitian secara khusus yang berkaitan dengan pengembangan model pembelajaran matematika berbasis masalah setting kooperatif untuk meningkatkan daya matematis dan keterampilan sosial. Karena itu tujuan penelitian ini adalah untuk memperoleh gambaran pembelajaran matematika di MTs. pada saat ini dan untuk memperoleh model pembelajaran matematika berbasis masalah setting kooperatif yang valid, praktis, dan efektif untuk meningkatkan daya matematis dan keterampilan sosial siswa kelas VIII MTs. Negeri Model Makassar. Berdasarkan masalah di atas, maka dilakukan rencana pemecahan masalah, yaitu mengembangkan model pembelajaran 
matematika dengan menggabungkan model pembelajaran berbasis masalah dengan model pembelajaran kooperatif yang akan diimplementasikan dengan tujuan meningkatkan daya matematis dan keterampilan sosial.

Model PBMSK dirancang berdasarkan tujuan pembelajaran dan jenis pengetahuan yang akan diajarkan, yaitu untuk meningkatkan kemampuan matematis, keterampilan sosial, dan pengetahuan deklaratif, serta pengetahuan prosedural. Oleh karena itu, dalam setiap fase dalam model yang dikembangkan menggunakan pendekatan student centered.

Secara singkat diuraikan komponenkomponen model yang dikembangkan, yaitu: (1) sintaks model PBMSK. Sintaks model PBMSK yang dikembangkan terdiri atas tujuh fase, yaitu: fase-1 menyampaikan tujuan dan orientasi siswa pada masalah, fase-2 mengorganisasikan siswa dalam kelompok belajar, fase-3 membimbing penyelidikan individual maupun kelompok, fase4 mengembangkan dan menyajikan hasil karya, fase-5 menganalisis dan mengevaluasi proses pemecahan masalah, fase- 6 evaluasi, dan fase- 7 memberi penghargaan, (2) sistem sosial model PBMSK. Menurut Suradi (2005: 39-40) komunikasi antara guru dengan siswa dapat dibagi dalam lima pola, yaitu: (a) pola "Guru (G) - Siswa (S)", (b) pola " Guru (G) - Siswa (S) Guru (G), (c) pola "Guru (G) - Siswa (S) - Siswa (S)", (d) pola "Guru (G) - Siswa (S), Siswa (S) Guru (G), Siswa (S) - Siswa (S), dan (e) pola melingkar, (3) Prinsip reaksi model PBMSK. Menurut Joyce, Weil, \& Shower (2009) bahwa prinsip reaksi merupakan pedoman bagi guru dalam menghargai dan merespons stimulus berupa prilaku-prilaku siswa dalam proses pembelajaran. (4) Sistem pendukung model PBMSK. Menurut Joyce \& Weil (2009) bahwa yang dimaksud sistem pendukung adalah segala sarana, bahan, dan alat yang diperlukan untuk melaksanakan model tersebut. (5) Dampak instruksional dan dampak pengiring. Menurut Joyce \& Weil (2009) bahwa dampak instruksional adalah tujuan utama yang bersifat segera/mendesak untuk dicapai (instructional effect) yaitu hasil belajar yang dicapai langsung dengan cara mengarahkan para siswa pada tujuan yang diharapkan sedangkan dampak pengikut/pengiring yaitu hasil belajar lainnya yang dihasilkan oleh suatu proses pembelajaran, sebagai akibat terciptanya suasana belajar yang dialami langsung oleh para siswa tanpa pengarahan langsung dari guru.

Selanjutnya, menurut Plomp (dalam Nurdin, 2007) memperkenalkan desain pendidikan yang disebut model umum untuk pemecahan masalah pendidikan. Lebih lanjut, Plomp menyatakan desain pendidikan model umum tersebut memuat lima fase, yaitu (1) fase preliminary investigation (investigasi awal), (2) fase design (desain), (3) fase realization/construct-ion (realisasi/konstruksi), (4) fase test, evaluation \& revision (tes, evaluasi \& revisi), dan (5) fase implementation (implementasi). Dalam penelitian ini menggunakan pengembangan model menurut Plomp (1997), yang meliputi: (a) prilemenary investigation, (2) design, (3) realization/construction, (4) test, evaluation, dan revision, dan (5) implementation.

Pengembangan model PBMSK yang telah diuraikan di atas, dirangkum dalam bentuk kerangka piker pada Gambar 1 berikut ini. 


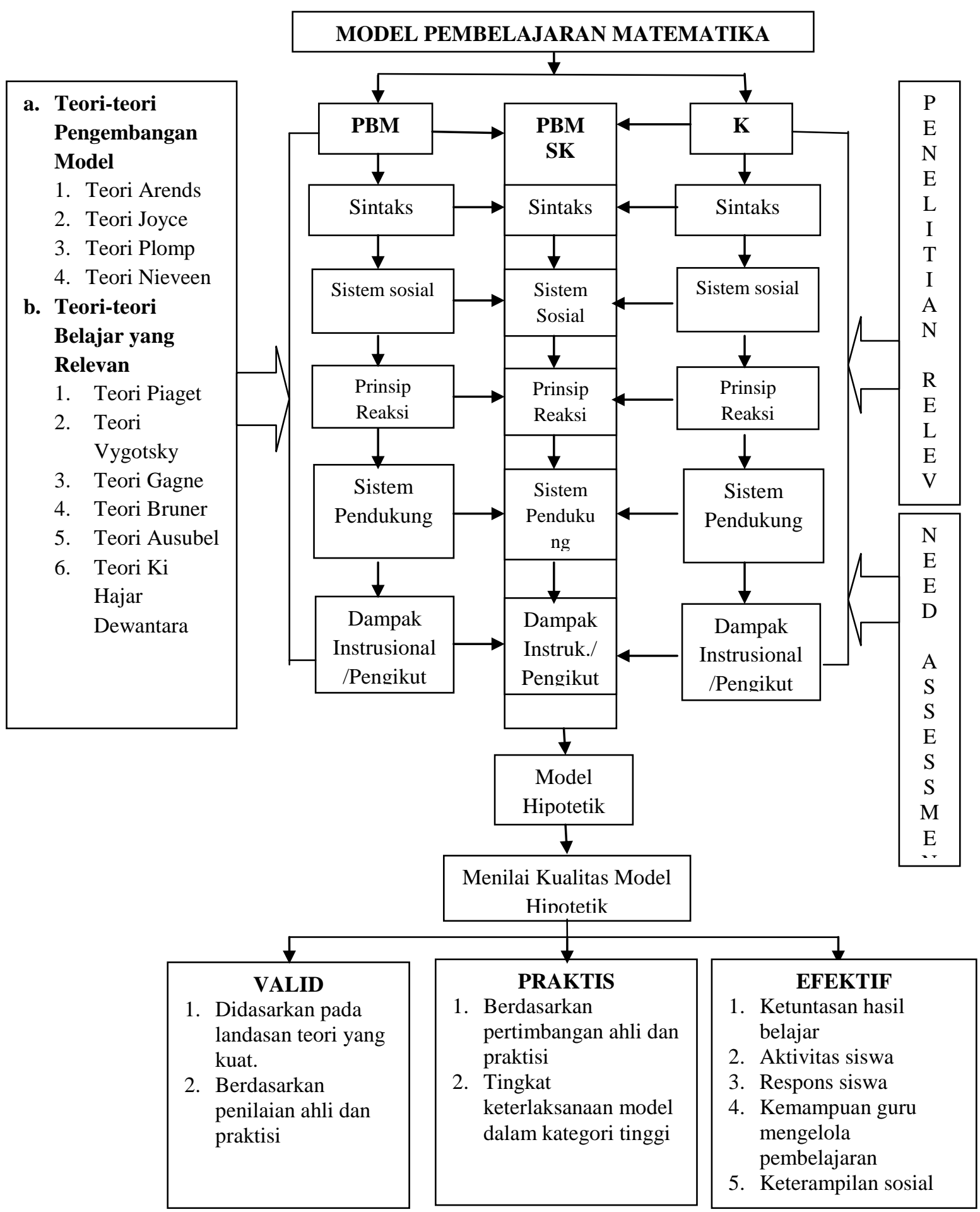

Gambar 1: Kerangka piker pengembangan model PBMSK. 
Kemudian selanjutnya dikembangkan pula model hipotetik beserta komponen-komponennya sebagaimana yang terangkum pada Gambar 2 berikut ini.

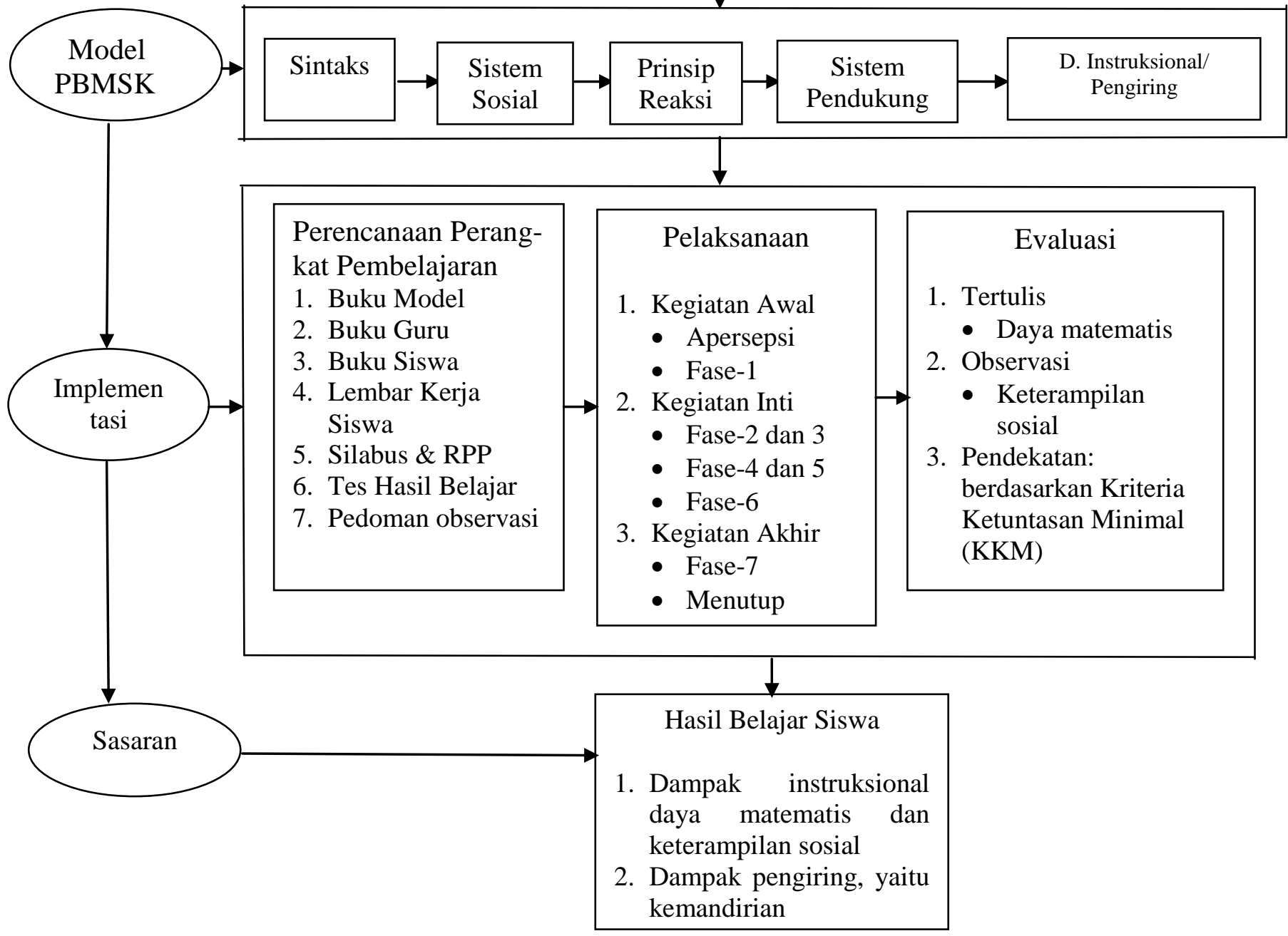

Gambar 2: Model hipotetik Pengembangan model PBMSK 


\section{METODE PENELITIAN}

Penelitian ini merupakan jenis penelitian dan pengembangan (Research and Development atau $R \& D$ ). Fase-fase yang ditempuh dalam mengembangkan model ini mengikuti fase-fase pengembangan model umum pemecahan masalah pendidikan yang dikemukakan oleh Plomp (dalam Djadir, 2008), yaitu: fase-1 investigasi awal, fase-2 perancangan, fase-3 realisasi/konstruksi, fasetes, evaluasi, dan revisi, dan fase-5 implementasi.

Hasil pengembangan model yang terdiri atas: buku model, buku guru, buku siswa, RPP, LKS, dan THB diujicobakan pada siswa kelas VIII-1 MTs. N Model Makassar. Selanjutnya untuk pengumpulan data diperoleh melalui: (1) data hasil validasi ahli dan praltisi, (2) data hasil belajar, (3) data aktivitas siswa, (4) data pengelolaan pembelajaran, (5) data respons siswa, dan (6) data respons guru.

Kemudian untuk teknik analisis data dilakukan dengan cara sebagai berikut, yaitu: (1) analisis data kevalidan, (2) analisis data kepraktisan, dan (3) analisis data keefektifan

\section{HASIL DAN PEMBAHASAN}

\section{Hasil}

Hasil penelitian pendahuluan memberikan informasi bahwa pelaksanaan pembelajaran matematika pada siswa kelas VIII MTs masih menggunakan Kurikulum Tingkat Satuan Pendidikan (KTSP) Tahun 2006 dan guru mengajar masih menggunakan paradigm lama yaitu pembelajaran langsung secara klaksikal. Konsep dan aturan matematika disajikan secara langsung dari guru ke siswa, menjelaskan materi, pemberian contoh-contoh, pemberian tugas, dan interaksi satu arah.

Hasil penelitian pendahuluan juga menunjukkan bahwa pembelajaran matematika sangat jarang melibatkan siswa untuk berdiskusi secara berkelompok. Beberapa aktivitas dalam belajar hanya sebatas pada: (1) mendengarkan penjelasan guru, (2) menyelesaikan soal-soal rutin, (3) mencatat penjelasan guru yang dianggap penting, dan (4) melakukan aktivitas yang tidak relevan dengan kegiatan pembelajaran. Pembelajaran masih didominasi guru dan kurang mengaitkan materi pembelajaran matematika dengan kehidupan nyata (kehidupan sehari-hari).

Berdasarkan penelitian pendahuluan terhadap aspek keterampilan sosial secara keseluruhan masih berada pada kualifikasi rendah. Hal tersebut sebagai dampak dari penerapan model yang digunakan selama ini belum terwujud secara optimal. Model yang dimaksud adalah model pembelajaran kooperatif, menurut Muslimin Ibrahim \& dkk (2000) bahwa ada tiga tujuan pembelajaran kooperatif, yaitu: (1) hasil belajar akademik, (2) penerimaan terhadap keragaman, dan (3) pengembangan keterampilan sosial.

Kondisi pembelajaran matematika di lapangan menunjukkan bahwa guru belum mengoptimalkan model-model pembelajaran di kelas yang relevan dengan karakteristik dan tujuan pembelajaran matematika. Penerapan pembelajaran matematika yang sedang berjalan saat ini juga belum mengacu pada model pembelajaran berbasis masalah setting kooperatif untuk meningkatkan daya matematis dan keterampilan sosial

Kondisi pembelajaran matematika di lapangan menunjukkan bahwa guru belum mengoptimalkan model-model pembelajaran di kelas yang relevan dengan karakteristik dan tujuan pembelajaran matematika. Penerapan pembelajaran matematika yang sedang berjalan saat ini juga belum mengacu pada model pembelajaran berbasis masalah setting kooperatif untuk meningkatkan daya matematis dan keterampilan sosial

Selanjutnya model PBMSK yang telah dikembangkan berupa prototipe-1 divalidasi oleh tiga orang validator, yang terdiri atas: dua orang pakar/ahli dan satu orang praktisi. Berdasarkan penilaian ketiga validator dapat dilihat pada Tabel berikut. 
Tabel 1. Hasil Penilaian Validator Terhadap Buku Model dan Seluruh Perangkat Pembelajaran

\begin{tabular}{c|c|c|c|c|c}
\hline Buku Model & Buku Guru & Buku Siswa & RPP & LKS & THB \\
\hline 3,91 & 3,62 & 3,60 & 3,63 & 3,54 & 3,65 \\
\hline
\end{tabular}

Berdasarkan Tabel 1 di atas, buku siswa, RPP, LKS, dan THB tersebut dapat menunjukkan bahwa tingkat kevalidan buku digunakan dengan revisi kecil.

model adalah $\bar{x}=3,91$ (sangat valid), buku guru $\bar{x}=3,62$ (sangat valid), buku siswa $\bar{x}=3,60$ (sangat valid), RPP $\bar{x}=3,63$ (sangat valid), LKS $\bar{x}=3,54$ (sangat valid), THB $\bar{x}=3,65$ (sangat

Berdasarkan hasil uji coba, maka keterlaksanaan sintaks diperoleh hasil sebagaimana yang diuraikan pada Tabel berikut ini. valid). Oleh karena itu, buku model, buku guru,

Tabel 2. Hasil Pengamatan Keterlaksanaan Komponen Sintaks

\begin{tabular}{|c|c|c|c|c|c|c|c|c|c|c|c|c|c|}
\hline \multirow{3}{*}{ Aspek Pengamatan } & \multicolumn{12}{|c|}{ Hasil Pengamatan } & \\
\hline & \multicolumn{2}{|c|}{$\mathrm{P}-1$} & \multicolumn{2}{|c|}{$\mathrm{P}-2$} & \multicolumn{2}{|c|}{ P-3 } & \multicolumn{2}{|c|}{$\mathrm{P}-4$} & \multicolumn{2}{|c|}{ P-5 } & \multicolumn{2}{|c|}{ P-6 } & \\
\hline & A & $\mathrm{B}$ & $\mathrm{A}$ & $\mathrm{B}$ & $\mathrm{A}$ & $\mathrm{B}$ & A & $\mathrm{B}$ & A & $\mathrm{B}$ & $\mathrm{A}$ & $\mathrm{B}$ & \\
\hline $\begin{array}{l}\text { 1. Menyampaikan tujuan dan } \\
\text { orientasi siswa pada masalah }\end{array}$ & 1 & 2 & 1 & 2 & 1 & 2 & 2 & 2 & 2 & 2 & 2 & 2 & \\
\hline $\begin{array}{l}\text { 2. Mengorganisasikan siswa dalam } \\
\text { belajar }\end{array}$ & 2 & 2 & 2 & 2 & 2 & 1 & 2 & 2 & 2 & 2 & 2 & 2 & \\
\hline $\begin{array}{l}\text { 3. Membimbing penyelidikan } \\
\text { individual maupun kelompok }\end{array}$ & 1 & 2 & 2 & 2 & 1 & 2 & 2 & 2 & 2 & 2 & 2 & 2 & \\
\hline $\begin{array}{l}\text { 4. Mengembangkan dan } \\
\text { menyajikan hasil karya }\end{array}$ & 2 & 1 & 2 & 2 & 1 & 2 & 1 & 2 & 2 & 2 & 2 & 2 & \\
\hline $\begin{array}{l}\text { 5. Refleksi pada pemecahan } \\
\text { masalah }\end{array}$ & 2 & 2 & 1 & 2 & 2 & 2 & 2 & 2 & 2 & 2 & 2 & 2 & \\
\hline 6. Evaluasi pembelajaran & 2 & 2 & 2 & 2 & 2 & 2 & 2 & 2 & 2 & 2 & 2 & 2 & \\
\hline 7. Memberikan penghargaan & 2 & 2 & 2 & 2 & 2 & 2 & 2 & 2 & 2 & 2 & 2 & 2 & \\
\hline Agreement & \multicolumn{2}{|c|}{7} & \multicolumn{2}{|c|}{7} & \multicolumn{2}{|c|}{7} & \multicolumn{2}{|c|}{7} & \multicolumn{2}{|c|}{7} & \multicolumn{2}{|c|}{7} & 42 \\
\hline Disagreement & \multicolumn{2}{|c|}{0} & \multicolumn{2}{|c|}{0} & \multicolumn{2}{|c|}{0} & \multicolumn{2}{|c|}{0} & \multicolumn{2}{|c|}{0} & \multicolumn{2}{|c|}{0} & 0 \\
\hline Rata-rata Pengamatan $(\bar{x})$ & \multicolumn{2}{|c|}{1,79} & \multicolumn{2}{|c|}{1,86} & \multicolumn{2}{|c|}{1,71} & \multicolumn{2}{|c|}{1,93} & \multicolumn{2}{|c|}{2,00} & \multicolumn{2}{|c|}{2,00} & 1,89 \\
\hline
\end{tabular}

Hasil pengamatan terhadap keterlaksanaan komponen sintaks pada Tabel 2 di atas, rata-rata pengamatan adalah 1,89 dan agreement dua pengamat sebanyak 35 dan tidak ada disagreement, berarti dua pengamat sepakat

Japar, Model Pembelajaran Berbasis Masalah......

Tabel 3. Hasil Pengamatan Keterlaksanaan Komponen Sistem Sosial 


\begin{tabular}{|c|c|c|c|c|c|c|c|c|c|c|c|c|c|}
\hline \multirow{3}{*}{ Aspek Pengamatan } & \multicolumn{12}{|c|}{ Hasil Pengamatan } & \\
\hline & \multicolumn{2}{|c|}{ P-1 } & \multicolumn{2}{|c|}{ P-2 } & \multicolumn{2}{|c|}{$\mathbf{P}-3$} & \multicolumn{2}{|c|}{ P-4 } & \multicolumn{2}{|c|}{ P-5 } & \multicolumn{2}{|c|}{ P-6 } & \\
\hline & $\mathbf{A}$ & B & $\mathbf{A}$ & B & $\mathbf{A}$ & B & $\mathbf{A}$ & B & $\mathbf{A}$ & B & $\mathbf{A}$ & B & \\
\hline $\begin{array}{l}\text { 1. Interaksi antarpeserta didik serta } \\
\text { antara peserta didik dengan } \\
\text { guru, lingkungan, dan sumber } \\
\text { belajar lainnya }\end{array}$ & 1 & 1 & 2 & 2 & 1 & 2 & 1 & 2 & 2 & 2 & 2 & 2 & \\
\hline $\begin{array}{l}\text { 2. Keaktifan peserta didik dalam } \\
\text { setiap kegiatan pembelajaran }\end{array}$ & 1 & 2 & 2 & 2 & 2 & 1 & 2 & 2 & 2 & 2 & 2 & 2 & \\
\hline $\begin{array}{l}\text { 3. Keaktifan peserta didik dalam } \\
\text { memahami masalah untuk } \\
\text { memperoleh } \\
\text { masalah dalam LKS }\end{array}$ & 1 & 2 & 2 & 2 & 2 & 2 & 2 & 1 & 2 & 2 & 2 & 2 & \\
\hline 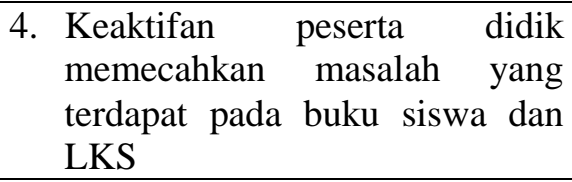 & 2 & 2 & 2 & 1 & 2 & 2 & 2 & 2 & 2 & 2 & 2 & 2 & \\
\hline $\begin{array}{l}\text { 5. Menumbuhkan } \\
\text { sosial dengan sesama peserta } \\
\text { didik }\end{array}$ & 1 & 2 & 1 & 2 & 1 & 2 & 2 & 2 & 2 & 2 & 2 & 2 & \\
\hline $\begin{array}{l}\text { 6. Memotivasi peserta didik yang } \\
\text { kurang atau } \\
\text { berpartisipasi aktif }\end{array}$ & 2 & 2 & 2 & 2 & 2 & 2 & 2 & 2 & 2 & 2 & 2 & 2 & \\
\hline Agreement & & & & & & 5 & & & & & & & 36 \\
\hline Disagreement & & & & & & ) & & & & & & & 0 \\
\hline Rata-rata Pengamatan $(\bar{x})$ & & & & & & 75 & & & & & & & 1,84 \\
\hline
\end{tabular}

Hasil pengamatan terhadap keterlaksanaan komponen sistem sosial pada Tabel 3. di atas, ratarata hasil dua pengamat adalah 1,84 sedangkan agreement dua pengamat sebanyak 30 dan tidak ada disagreement, berarti dua pengamat sepakat bahwa komponen sistem social terlaksana dengan percentage of agreement $(\mathrm{PA})=100 \%)$. Jika dikonfirmasi dengan kriteria keterlaksanaan yang telah ditetapkan, maka disimpulkan komponen sistem sosial terlaksana seluruhnya $(1,5 \leq \bar{x} \leq 2,0)$.

Tabel 4. Hasil Pengamatan Keterlaksanaan Komponen Prinsip Reaksi

\begin{tabular}{|c|c|c|c|c|c|c|c|c|c|c|c|c|c|}
\hline \multirow{3}{*}{ Aspek Pengamatan } & \multicolumn{12}{|c|}{ Hasil Pengamatan } & \\
\hline & \multicolumn{2}{|c|}{$\mathrm{P}-1$} & \multicolumn{2}{|c|}{$\mathrm{P}-2$} & \multicolumn{2}{|c|}{$\mathrm{P}-3$} & \multicolumn{2}{|c|}{ P-4 } & \multicolumn{2}{|c|}{ P-5 } & \multicolumn{2}{|c|}{ P-6 } & \\
\hline & A & B & A & B & A & $\mathrm{B}$ & $\mathrm{A}$ & $\mathrm{B}$ & $\mathrm{A}$ & B & $\mathrm{A}$ & $\mathrm{B}$ & \\
\hline $\begin{array}{l}\text { 1. Guru merespons } \\
\text { partisipasi peserta didik }\end{array}$ & 2 & 2 & 2 & 2 & 2 & 2 & 2 & 2 & 2 & 2 & 2 & 2 & \\
\hline $\begin{array}{l}\text { 2. Guru menunjukkan } \begin{array}{r}\text { sikap } \\
\text { terbuka terhadap } \\
\text { peserta didik }\end{array} \\
\end{array}$ & 2 & 2 & 2 & 2 & 2 & 2 & 2 & 2 & 2 & 2 & 2 & 2 & \\
\hline $\begin{array}{l}\text { 3. Guru memotivasi peserta didik } \\
\text { dan menciptakan suasana yang } \\
\text { kondusif untuk belajar }\end{array}$ & 2 & 1 & 2 & 2 & 2 & 2 & 2 & 2 & 2 & 2 & 2 & 2 & \\
\hline
\end{tabular}




\begin{tabular}{|c|c|c|c|c|c|c|c|c|c|c|c|c|c|c|}
\hline & $\begin{array}{l}\text { Guru menyediakan dan } \\
\text { mengelola sumber belajar yang } \\
\text { sesuai dengan kompetensi yang } \\
\text { akan dicapai }\end{array}$ & 2 & 2 & 1 & 2 & 1 & 2 & 1 & 2 & 2 & 2 & 2 & 2 & \\
\hline 5 . & $\begin{array}{l}\text { Guru memperhitungkan } \\
\text { rasionalitas alokasi waktu pada } \\
\text { setiap pembelajaran pada buku } \\
\text { siswa dan LKS }\end{array}$ & 1 & 2 & 2 & 2 & 1 & 2 & 2 & 2 & 2 & 2 & 2 & 2 & \\
\hline 6. & $\begin{array}{l}\text { Guru membimbing peserta didik } \\
\text { dalam menyelesaikan masalah } \\
\text { pada buku siswa }\end{array}$ & 2 & 2 & 1 & 2 & 2 & 2 & 2 & 2 & 2 & 2 & 2 & 2 & \\
\hline & $\begin{array}{l}\text { Guru memberikan penguatan } \\
\text { kepada peserta didik }\end{array}$ & 2 & 1 & 2 & 2 & 2 & 2 & 2 & 2 & 2 & 2 & 2 & 2 & \\
\hline & $\begin{array}{l}\text { Guru memberikan penghargaan } \\
\text { kepada peserta didik }\end{array}$ & 2 & 2 & 2 & 2 & 2 & 2 & 2 & 2 & 2 & 2 & 2 & 2 & \\
\hline & Agreement & \multirow{2}{*}{\multicolumn{2}{|c|}{0}} & & \multicolumn{2}{|c|}{8} & \multicolumn{2}{|c|}{8} & & \multicolumn{2}{|l|}{8} & 48 \\
\hline & Disagreement & & & \multicolumn{2}{|c|}{0} & \multicolumn{2}{|c|}{0} & ( & & \multicolumn{2}{|c|}{0} & \multicolumn{2}{|l|}{0} & 0 \\
\hline & Rata-rata Pengamatan $(\bar{x})$ & \multicolumn{2}{|c|}{1,81} & \multicolumn{2}{|c|}{1,88} & \multicolumn{2}{|c|}{1,88} & \multicolumn{2}{|c|}{1,94} & \multicolumn{2}{|c|}{2,00} & \multicolumn{2}{|c|}{2,00} & 1,92 \\
\hline
\end{tabular}

Hasil pengamatan terhadap keterlaksanaan komponen prinsip reaksi pada Tabel 4. di atas, rata-rata dua pengamat adalah 1,92 sedangkan agreement dua pengamat sebanyak 40 dan tidak ada disagreement, berarti dua pengamat sepakat bahwa komponen prinsip reaksi terlaksana dengan percentage of agreement $(\mathrm{PA})=100 \%)$. Jika dikonfirmasi dengan kriteria keterlaksanaan yang telah ditetapkan, maka disimpulkan bahwa komponen prinsip reaksi terlaksana seluruhnya $(1,5 \leq \bar{x} \leq 2,0)$.

Tabel 5. Hasil Pengamatan Keterlaksanaan Komponen Sistem Pendukung

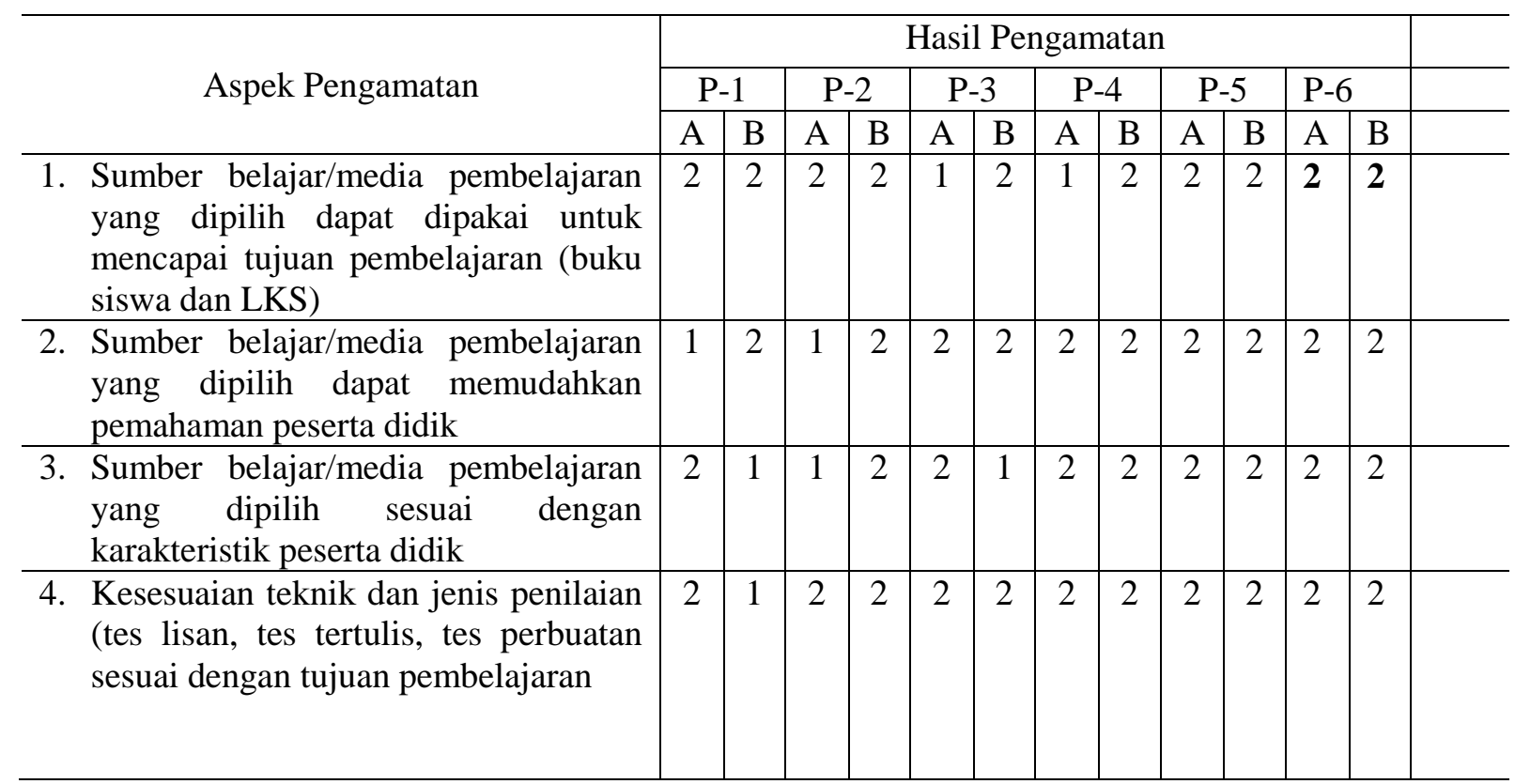




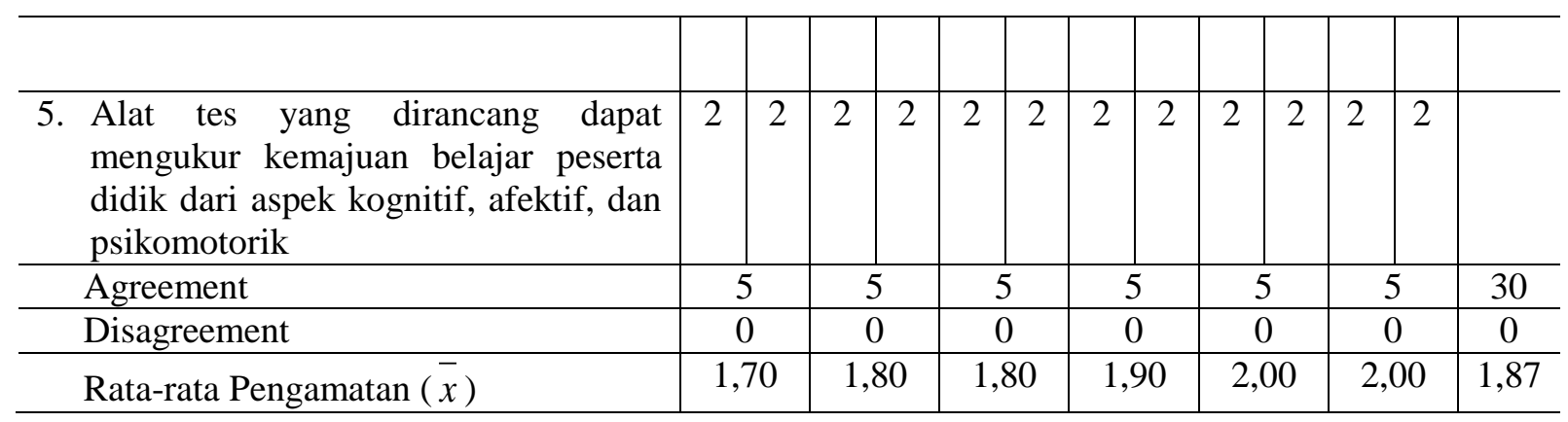

Hasil pengamatan terhadap keterlaksanaan komponen sistem pendukung pada Tabel 5. di atas, rata-rata hasil dua pengamat adalah 1,87 sedangkan agreement dua pengamat sebanyak 25 dan tidak ada disagreement 0 , berarti dua pengamat sepakat bahwa komponen sistem pendukung terlaksana dengan percentage of agreement $(\mathrm{PA})=100 \%$. Jika dikonfirmasi dengan kriteria keterlaksanaan yang telah ditetapkan, maka disimpulkan bahwa komponen

Tabel 6. Statistik Skor Daya Matematis Siswa

\begin{tabular}{c|c}
\hline Variabel & Nilai Statistik \\
\hline Subjek Penelitian & 40 \\
\hline Skor Ideal & 100 \\
\hline Rata-Rata & 89,20 \\
\hline Standar Deviasi & - \\
\hline Rentang Skor & 34 \\
\hline Skor Maksimum & 100 \\
\hline Skor Minimum & 66 \\
\hline
\end{tabular}

sistem pendukung terlaksana seluruhnya $(1,5 \leq$ $\bar{x} \leq 2,0)$.

Berdasarkan uraian di atas, maka hasil pengamatan keterlaksanaan pembelajaran telah memenuhi kriteria kepraktisan yang telah ditetapkan

Selanjutnya akan diuraikan hasil uji keefektifan model pada Tabel 6. S.d 7 berikut ini.

Pada Tabel 6. di atas, menunjukkan bahwa skor rata-rata 89,20 dari skor ideal 100. jika dirujuk pada kriteria ketuntasan belajar klasikal, maka dapat disimpulkan bahwa telah memenuhi ketuntasan klasikal. Selanjutnya pada pembelajaran pertemuan-1 sampai dengan pertemuan-6 juga dilakukan penilaian tentang daya matematis. Nilai hasil belajar siswa tersebut dapat dilihat pada Tabel 7. berikut ini.

Tabel 7. Rata-rata Nilai Daya Matematis Mulai dari Pertemuan-1 sampai dengan Pertemuan-6

\begin{tabular}{c|l|c|c|c|c|c|c}
\hline \multirow{2}{*}{ No } & \multirow{2}{*}{ Daya Matematis } & \multicolumn{7}{c}{ Rata-Rata/Pertemuan } \\
\cline { 3 - 8 } & & 1 & 2 & 3 & 4 & 5 & 6 \\
\hline 1 & Pemahaman Konsep & 5,25 & 5,75 & 6,33 & 6,73 & 7,35 & 8,13 \\
\hline 2 & Pemecahan Masalah & 15,85 & 16,70 & 17,63 & 18,48 & 20,30 & 21,53 \\
\hline 3 & Penalaran Matematis & 16,00 & 16,83 & 17,53 & 18,33 & 20,50 & 21,38 \\
\hline 4 & Komunikasi Matematis & 13,13 & 14,08 & 14,35 & 14,70 & 15,75 & 17,35 \\
\hline 5 & Koneksi Matematis & 13,03 & 13,03 & 14,33 & 14,75 & 15,28 & 16,58 \\
\hline & Rata-Rata Nilai & 63,26 & 66,39 & 70,17 & 71,99 & 79,18 & 84,97 \\
\hline
\end{tabular}

Berdasarkan Tabel 7. di atas, menunjukkan bahwa pemahaman konsep, pemecahan masalah, penalaran matematis, komunikasi matematis dan koneksi matematis, meningkat dari pertemuan-1 sampai dengan pertemuan-6. Dengan demikian, penerapan model dapat meningkat daya 
matematis siswa. Selanjutnya proses pembelajaran juga dilakukan penilaian sikap melalui pengamatan pada aspek keterampilan sosial, dari pertemuan-1 sampai pada pertemuan6 pada Tabel 8 . berikut ini.

Tabel 8. Hasil Pengamatan Keterampilan Sosial

\begin{tabular}{l|c|c|c|c|c|c}
\hline Keterampilan Sosial & \multicolumn{7}{|c}{ Pertemuan } \\
\hline & 1 & 2 & 3 & 4 & 5 & 6 \\
\hline Empati & 63 & 72 & 72 & 79 & 85 & 85 \\
\hline Kerjasama & 69 & 75 & 82 & 85 & 88 & 94 \\
\hline Toleransi & 63 & 69 & 75 & 82 & 82 & 88 \\
\hline Solidaritas & 66 & 69 & 75 & 85 & 85 & 91 \\
\hline Demokrasi & 66 & 72 & 72 & 82 & 85 & 88 \\
\hline Komunikasi & 60 & 66 & 69 & 79 & 82 & 85 \\
\hline \multicolumn{1}{c|}{ Jumlah } & 387 & 423 & 445 & 492 & 507 & 531 \\
\hline \multicolumn{1}{c|}{ Rata-Rata } & 64,50 & 70,50 & 74,17 & 82,00 & 84,50 & 88,50 \\
\hline
\end{tabular}

Berdasarkan Tabel 8. di atas, menunjukkan sikap empati, kerjasama, toleransi, demokrasi,dan komunikasi siswa meningkat dari pertemuan-1 sampai dengan pertemuan-6. Dengan demikian, penerapan model dapat meningkatkan keterampilan sosial siswa.

Secara keseluruhan menunjukkan bahwa:

(1) aspek ketuntasan belajar klasikal, (2) daya matematis, dan (3) keterampilan sosial siswa telah memenuhi kriteria sebagaimana yang telah ditetapkan. Berikut ini data hasil pengamatan terhadap aktivitas siswa selama enam kali pertemuan disajikan pada Tabel 9. berikut ini.

Tabel 9. Rerata Persentase Waktu Aktivitas Siswa

\begin{tabular}{l|c|c|c|c|c|c|c|c|c}
\hline \multirow{2}{*}{ Pertemuan } & \multicolumn{7}{|c}{ Persentase Rerata Frekuensi Aktivitas Siswa Untuk Setiap Kategori } \\
\cline { 2 - 10 } & 1 & 2 & 3 & 4 & 5 & 6 & 7 & 8 & 9 \\
\hline I $\left(3 \times 40^{\prime}\right)$ & 9,17 & 10,63 & 12,91 & 22,91 & 11,46 & 12,71 & 12,50 & 5,63 & 2,79 \\
\hline II $\left(2 \times 40^{\prime}\right)$ & 10,00 & 10,63 & 12,51 & 24,38 & 12,19 & 11,25 & 12,19 & 5,00 & 1,25 \\
\hline III (3x40') & 10,21 & 11,05 & 13,75 & 25,21 & 11,46 & 11,04 & 11,04 & 5,21 & 1,25 \\
\hline IV (2x40') & 11,14 & 12,20 & 12,20 & 23,77 & 11,75 & 11,58 & 11,25 & 6,00 & 0,00 \\
\hline V (3x40') & 10,63 & 10,84 & 11,27 & 26,46 & 11,05 & 11,26 & 11,05 & 5,42 & 0,00 \\
\hline VI (2x40') & 10,94 & 11,88 & 12,07 & 25,94 & 10,32 & 10,94 & 11,25 & 5,94 & 0,00 \\
\hline $\begin{array}{l}\text { Rerata } \\
\text { Prosentase }\end{array}$ & 10,35 & 11,21 & 12,45 & 24,77 & 11,54 & 11,46 & 11,55 & 5,53 & 0,88 \\
\hline
\end{tabular}

Berdasarkan Tabel 9. di atas, menunjukkan bahwa persentase waktu aktivitas siswa, jika dirujuk pada kriteria pencapaian persentase waktu ideal aktivitas siswa yang telah ditetapkan, maka dapat disimpulkan bahwa telah terpenuhi kriteria pencapaian persentase waktu ideal yang ditetapkan. Kemudian untuk data hasil pengamatan kemampuan guru mengelola pembelajaran dapat dilihat pada Tabel 10 . berikut ini. 
Tabel 10. Rerata Kemampuan Guru Mengelola Pembelajaran

\begin{tabular}{c|c|c|c}
\hline Tahap & $\begin{array}{c}\text { Percentage of } \\
\text { Agrements }(\%)\end{array}$ & Rata-rata Pengamatan & Kategori \\
\hline Tahap-1 & 92 & 3,90 & Sangat Baik \\
\hline Tahap-2 & 96 & 3,78 & Sangat Baik \\
\hline Tahap-3 & 92 & 3,57 & Sangat Baik \\
\hline Tahap-4 & 100 & 3,90 & Sangat Baik \\
\hline Tahap-5 & 100 & 3,84 & Sangat Baik \\
\hline Tahap-6 & 100 & 3,92 & Sangat Baik \\
\hline Tahap-7 & 100 & 4,00 & Sangat Baik \\
\hline Penutup & 100 & 4,00 & Sangat Baik \\
\hline Alokasi Waktu & 100 & 3,88 & Sangat Baik \\
\hline Suasana Kelas & 100 & 3,88 & Sangat Baik \\
\hline Rerata Total & 98 & 3,88 & Sangat Baik \\
\hline
\end{tabular}

Berdasarkan data pada Tabel 10. di atas, diperoleh nilai kategori kemampuan guru mengelola pembelajaran secara keseluruhan adalah 3,88 (sangat baik). Jika dirujuk terhadap kriteria yang telah ditetapkan, maka dapat disimpulkan bahwa tingkat kemampuan guru mengelola pembelajaran termasuk kategori sangat baik. Selanjutnya hasil analisis data respons siswa terhadap komponen dan kegiatan pembelajaran disajikan pada tabel 11 . berikut ini.

Tabel 11. Respons Siswa Terhadap Komponen dan Kegiatan Pembelajaran

\begin{tabular}{|c|c|c|c|}
\hline \multirow{2}{*}{ No } & \multirow{2}{*}{ Aspek Penilaian } & \multicolumn{2}{|c|}{ Persentase $(\%)$} \\
\hline & & Senang & Tidak Senang \\
\hline \multirow{7}{*}{1} & Bagaimana perasaanmu terhadap komponen & & \\
\hline & a. Materi pelajaran & 100 & 0 \\
\hline & b. Lembar Kerja Siswa & 95 & 5 \\
\hline & c. Media/Alat Peraga & 92,5 & 7,5 \\
\hline & d. Buku siswa & 100 & 0 \\
\hline & e. Suasana belajar di kelas & 90 & 10 \\
\hline & f. $\quad$ Cara guru mengajar & 100 & 0 \\
\hline \multirow{6}{*}{2} & Rerata & 96,25 & 3,75 \\
\hline & \multirow{2}{*}{ Aspek Penilaian } & \multicolumn{2}{|c|}{ Persentase $(\%)$} \\
\hline & & Bermi-nat & Tidak Berminat \\
\hline & $\begin{array}{l}\text { Pada masa yang akan datang, apakah anda berminat untuk } \\
\text { mengikuti pembelajaran dengan model PBMSK }\end{array}$ & 95 & 5 \\
\hline & \multirow{2}{*}{$\begin{array}{l}\text { Berikan komentar anda mengenai buku siswa dan LKS yang telah } \\
\text { anda gunakan }\end{array}$} & \multicolumn{2}{|c|}{ Persentase $(\%)$} \\
\hline & & Ya & Tidak \\
\hline & $\begin{array}{l}\text { a. Apakah menurut anda buku siswa dan LKS itu mudah dibaca } \\
\text { b. Apakah buku siswa dan LKS itu menggunakan bahasa yang } \\
\text { pada umumnya sudah dikenal } \\
\text { c. Apakah menurut anda penampilan buku siswa dan LKS itu } \\
\text { menarik }\end{array}$ & $\begin{array}{l}92,5 \\
95 \\
92,5\end{array}$ & $\begin{array}{r}7,5 \\
5 \\
7,5\end{array}$ \\
\hline & Rerata & 93,33 & 6,67 \\
\hline & Rerata Total & 94,86 & 5,14 \\
\hline
\end{tabular}


Berdasarkan data pada Tabel 11. di atas, menunjukkan bahwa: (1) rerata respons siswa menyatakan senang terhadap komponen dan kegiatan pembelajaran adalah $96,25 \%$, (2) Sedangkan yang merespons bahwa di masa yang akan datang berminat mengikuti pembelajaran dengan model PBMSK, yaitu 95,5\% (2) rerata respons siswa menyatakan berminat mengikuti pembelajaran matematika pada materi yang lain dengan model PBMSK adalah 95\%, dan (3) respons siswa menyatakan buku siswa dan LKS mudah dibaca adalah 92,5\%, menyatakan buku siswa dan LKS menggunakan bahasa yang sederhana adalah 95\%, dan menyatakan buku siswa dan LKS menarik adalah 92,5\%. Jika dirujuk pada kriteria keefektifan yang telah ditetapkan pada, maka dapat disimpulkan bahwa telah memenuhi kriteria keefektifan

Dengan demikian, pengembangan model yang telah dilakukan berdasarkan tahap-tahap pengembangan model, kemudian dilakukan validasi model dan ketiga validator menyatakan valid. Selanjutnya dilakukan uji coba. Hasil uji coba tersebut menunjukkan bahwa produk yang digunakan telah memenuhi kriteria kepraktisan dan keefektifan

\section{Pembahasan}

Beberapa hal yang menjadi temuan dalam penelitian ini dalam penerapan model PBMSK, sebagai berikut: hasil validasi model PBMSK oleh validator (dua orang ahli dan satu praktisi) diperoleh nilai model PBMSK dengan kategori sangat valid, yaitu dengan nilai rata-rata 3,91. Hal ini menunjukkan model PBMSK yang telah dikembangkan siap untuk diujicobakan. Berdasarkan hasil uji coba diperoleh kepraktisan model, yaitu: (a) keterlaksanaan komponen sintaks sebesar 1,89 (terlaksana seluruhnya), (b) keterlaksanaan komponen sistem sosial sebesar 1,84 (terlaksana seluruhnya), (c) keterlaksanaan komponen prinsip reaksi sebesar 1,92 (terlaksana seluruhnya), dan (d) keterlaksanaan komponen sistem pendukung sebesar 1,87 (terlaksana seluruhnya). Hasil uji coba juga menunjukkan bahawa ketuntasan klaksikal adalah $92,5 \%$ yaitu siswa yang memperoleh skor 75 ke atas. Sedangkan data hasil tes untuk mengukur peningkatan daya matematis menunjukkan bahwa: (a) pemahaman konsep memperoleh skor adalah 99,4\%, (b) penalaran matematis memperoleh skor adalah 78,3\%, (c) pemecahan masalah memperoleh skor adalah $92,5 \%$, (d) koneksi matematis memperoleh skor $85,9 \%$, dan (e) komunikasi matematis memperoleh skor adalah $83,1 \%$. Sementara penerapan model PBMSK dalam pembelajaran pada penelitian ini, diperoleh ketuntasan hasil belajar yang sangat tinggi baik secara individual maupun klaksikal yaitu $92,5 \%$, artinya dengan menerapkan model PBMSK telah meningkatkan hasil belajar matematika. Hal ini sejalan dengan hasil penelitian Ferreira MM \& Trudel RA (2012) bahwa penerapan Problem Based Learning dapat meningkatkan kemampuan yang signifikan terhadap sikap positif siswa dan kemampuan pemecahan masalah dan lingkungan belajar.. Secara individu ditemukan bahwa terdapat dua orang siswa yang memperoleh nilai di bawah kriteria ketuntasan, yaitu memperoleh nilai 66 dan 69 dan dua orang siswa yang memperoleh nilai 100. Hal yang menarik juga terlihat bahwa daya matematis, antara pemahaman konsep dengan pemecahan masalah berbanding lurus artinya ada kaitan antara siswa yang pemahaman konsep matematika tinggi, maka siswa tersebut lebih cepat memecahkan masalah matematis. Sedangkan hal lain juga yang ditemukan adalah antara penalaran matematis dengan pemecahan masalah berbading tidak lurus, yaitu 78,3\% dengan $92,5 \%$. Jika dirujuk pada pendapat Matlin (Nanang P, 2002) bahwa proses penalaran, pengambilan keputusan, dan pemecahan masalah merupakan aktivitas mental yang membentuk inti berpikir. Sehingga antara penalaran matematis dan pemecahan masalah merupakan satu kesatuan.

Hasil penelitian juga ditemukan bahwa aspek keteramapilan sosial yang meliputi: (1) empati terdiri atas: memadai $37,0 \%$; cukup 
memadai 56,5\%; kurang memadai 6,5\%; dan tidak memadai $0,0 \%$; (2) kerjasama yang terdiri atas: memadai $40,0 \%$; cukup memadai $41,5 \%$; kurang memadai $16,0 \%$; dan tidak memadai 2,0\%; (3) toleransi yang terdiri atas: memadai $34,0 \%$; cukup memadai $44,5 \%$; kurang memadai $16,5 \%$; dan tidak memadai 2,0\%; (4) solidaritas yang terdiri atas: memadai 46,0\%; cukup memadai 47,0\%; kurang memadai $5,0 \%$; dan tidak memadai $1,5 \%$ (5) demokratis yang terdiri atas: memadai $42,0 \%$; cukup memadai $51,0 \%$; kurang memadai $5,0 \%$; tidak memadai $1,5 \%$ (6) komunikasi yang terdiri atas: memadai $34,0 \%$; cukup memadai 55,0\%; kurang memadai $11,5 \%$; dan tidak memadai $0,0 \%$. Keterampilan sosial pada aspek kerjasama ditemukan 16,0\% siswa tidak senang bekerjasama dan aspek toleransi juga ditemukan 16,5\% tidak pekah terhadap kesulitan yang dialami oleh teman-temannya. Hal ini menunjukkan bahwa sikap kerjasama dipengaruhi sikap toleransi.

Temuan lain dalam penelitian ini adalah alasan siswa dalam merespon positif terhadap penerapan pembelajaran model PBMSK dan sistem pendukung model yaitu siswa menyatakan bahwa ternyata pada materi sistem persamaan linear dua variabel (SPLDV) sangat menarik karena seluruh masalah yang disajikan selalu dikaitkan dengan kehidupan nyata atau kehidupan sehari-hari serta dilengkapi dengan gambar yang sesuai dengan masalah tersebut. Hal ini, sejalan dengan pendapat Soedjadi (2000) bahwa, menetapkan masalah nyata dalam pelaksanaan pembelajaran matematika perlu memperhatikan realitas dan lingkungan yang ada, sehingga memungkinkan dan sekaligus dapat memotivasi siswa untuk senang belajar matematika. Penerapan model PBMSK dapat dikatakan relevan dengan kurikulum 2013. Hal ini, dapat ditemukan pada saat proses pembelajaran dan penilaian autentik. Oleh karena, setiap masalah yang diangkat dalam buku siswa maupun LKS berbasis pada kehidupan nyata, sehingga siswa dapat mengamati, mengklasfikasi, mengukur, menjelaskan, dan menyimpulkan masalah-masalah yang ada dalam LKS yang merupakan esensi aktivitas siswa dalam kegiatan pembelajaran yang sejalan dengan kurikulum 2013.

Temuan utama dari penelitian ini yang patut dipromosikan adalah model PBMSK yang memenuhi kriteria valid, praktis, dan efektif serta dapat meningkatkan ketuntasan belajar dan keterampilan sosial siswa

\section{SIMPULAN DAN SARAN}

Simpulan yang dapat ditarik dari penelitian ini adalah sebagai berikut : Kondisi pembelajaran matematika pada MTs. N Model Makassar pada saat ini adalah: (a) belum sepenuhnya mengacu pada tujuan pembelajaran matematika menurut NCTM (2000), (b) perangkat pembelajaran yang digunakan seperti buku guru, buku siswa, lembar kerja siswa, rencana pelaksanaan pembelajaran, dan tes hasil belajar masih merupakan barang jadi yang belum memenuhi karakteristik siswa dan kondisi madrasah, (c) kebiasaan mengajar guru masih merupakan kegiatan rutinitas. Model PBMSK dinyatakan oleh para ahli dan praktisi valid dan siap untuk diujicobakan. Setelah diujicobakan model dinyatakan praktis, karena hampir semua aspek dalam komponen model terlaksana seluruhnya, dan model juga dinyatakan efektif, karena ketuntasan belajar telah tercapai, aktivitas siswa sesuai yang diharapkan, kemampuan guru mengelola pembelajaran sangat baik, dan respon siswa terhadap pembelajaran sudah positif, serta keterampilan sosial siswa sudah meningkat. Dengan demikian pengembangan model PBMSK telah memenuhi kriteria valid, praktis dan efektif. Oleh karena itu, tujuan memperoleh model PBMSK yang berkualitas telah tercapai.

Berdasarkan hasil penelitian ini, dikemukakan beberapa saran sebagai berikut: Kepada guru matematika agar pembelajaran matematika berdasarkan tujuan pembelajaran matematika yang meliputi: (a) pemahaman konsep, (b) pemecahan masalah, (c) penalaran matematis, (d) koneksi matematis, dan (e) komunikasi matematis. Penerapan model PBMSK dalam pembelajaran matematika dapat dijadikan sebagai salah satu alternatif untuk 
meningkatkan daya matematis dan keterampilan sosial siswa. Pengembangan model PBMSK pembelajaran seperti ini seyogyanya juga dilakukan pada pokok bahasan lain untuk membuat siswa tertarik, senang, dan aktif dalam belajar matematika. Kepada Pusat Kurikulum dan Perbukuan, Kementerian Pendidikan dan Kebudayaan kiranya produk penelitian ini, yang terdiri atas: (a) buku model, (b) buku guru, (c) buku siswa, (d) LKS, (e) RPP, dan (f) tes hasil belajar dapat dijadikan sebagai referensi dalam penerapan kurikulum 2013

\section{DAFTAR RUJUKAN}

Depdiknas. 2006. Peraturan Menteri Pendidikan Nomor 22 Tahun 2006 tentang Standar Isi (SI). Jakarata: Depdiknas

Djadir. 2008. Pengembangan Model Pembelajaran Matematika dengan Menggunakan Kombinasi Pengajaran Langsung dan Pembelajaran Kooperatif (KPLPK). (http://pasca.unesa.ac.id/detail/beritapasca/pembelajaran-matematikadengan-menggunakan-model-kplpk. Selasa, 7 Januari 2014)

Hsiung, C.-M. 2012. The Effectiveness of Cooperative Learning. Journal of Engineering Education. January 2012, Vol. 101, No. 1, pp. 119-137 (C) 2012 ASEE. http://www.jee.org

Joyce , Weil, \& Marsha, 2009. Models of Teaching. Massachussetts: Allyn and Bacon

Monaghan. C. H. 2011. Communities of Practice: A Learning Strategy for Management Education (Journal of Management Education 2011 35: 428 originally published online 23 Nopember 2010)

Nurdin. 2007. Model Pembelajaran Matematika yang Menumbuhkan Kemampuan Metakognitif untuk Menguasai Bahan Ajar. Disertasi. Tidak diterbitkan. Surabaya: Program Pascasarjana Universitas Negeri Surabaya.
Rusman. 2011. Model-Model pembelajaran (Mengembangkan Profesionalisme Guru). Bandung: Mulia Mandiri Pers.

Suradi. 2006. Interaksi Siswa SMP dalam Pembelajaran Matematika Secara Kooperatif. Disertasi tidak diterbitkan. Program Pascasarjana Universitas Negeri Surabaya.

Suwarsono. 2002. Teori-teori Pembelajaran Matematika. Makalah disajikan pada Pelatihan Guru Matematika SMP. Tidak di terbitkan.

Slavin, R.E. 2005. Educational Psychology, Theories and Practice. Fourth Edition. Masschusetts. Allyn and Bacon Publishers. 